\title{
A Study in Cooperation with Japanese Universities on Cultivation of Talents of Japanese, Science and Technology
}

\author{
Hua Wang ${ }^{1}$ \\ ${ }^{1}$ Xi'an University, Xi'an City, Shaanxi Province, China
}

Keywords: Japanese; Science and technology; Cooperative cultivation

\begin{abstract}
With the flourishing development of information high-tech industry, the demand of Japanese talents is mainly on applied talents who specialize in both Japanese, science and technology. The $2+2$ cultivation project cooperated with Japanese university is the best way to achieve the cultivation of talents who specialize in Japanese and thoroughly understand science and technology. After two-year learning of basic language knowledge of Japanese in Chinese university, students choose a new specialty in Japanese university and develop a new professional skill.
\end{abstract}

\section{Introduction}

Current Situation of the Demand of Japanese Talents. In recent years, with the flourishing development of information high-tech industry, communications about economy, science and technology, education between China and Japan have become more and more frequent. The demand of Japanese talents rapidly increases. However, in terms of the feedback from some employers like middle and small-sized Japanese enterprises, ability of Japanese always comes first and technical background comes second in terms of the requirement of talents no matter in what industry and positions. The demand of Japanese talents is mainly on applied talents who specialize in both Japanese, science and technology. When the enterprises hire talents, they need talents who can speak Japanese and also have a good understanding of specialty, namely, talents of Japanese with science and technology. The so call Japanese with science and technology means specialty in Japanese and thoroughly understanding of science and technology. Specialty in Japanese requires substantial linguistic knowledge of Japanese and mastery of skills such as listening, speaking, reading, writing and translating. Thoroughly understanding of science and technology requires to learn a professional skill based on the certain ability of Japanese. The $2+2$ cultivation project cooperated with Japanese university is the best way to achieve the cultivation of talents who specialize in Japanese and thoroughly understand science and technology. After two-year learning of basic language knowledge of Japanese in Chinese university, students choose a new specialty in Japanese university and develop a new professional skill.

\section{Current Situation of Cooperation with Japanese University}

With a popularization tendency of higher education in China, higher education has formed not only a pattern of multilevel structure and diversified development, but also a school running mode from various channels and by various ways. Chen Zhili has mentioned in the opening ceremony of Chinese-Foreign University Presidents Forum in 2004 that through extensive international exchanges and cooperation, we can absorb advantages of different sides in the world, boldly absorb and use as reference the successful experience of educational development and management from many countries, introduce excellent cultural achievements from other countries, and improve the educational level and cultivation quality of talents in China. It is precisely because of the good situation and urgent demand of such international exchange and cooperation, the international exchange and cooperation about higher education in China has vigorously developed. Japan is an Asian developed country with advanced concepts and technologies in economy, science and technology and education. China, as a close neighbor of Japan that is separated only by a narrow strip of water, has the advantaged condition due to its geographic distribution. Therefore, the projects of communication and cooperation such as exchange student and cooperative cultivation 
between a Chinese university and a Japanese university are quite dynamic. The number of agreement with Chinese university signed by Japanese universities has been up to 3,361.

China scholarship council, a subordinate of China's ministry of education, has issued the first phase of situation of selected students sent by state construction high-level university according to government sponsored project for graduate student (2007-2011). Within these five years, there were 1,800 Chinese graduate students selected and sent to Japan. In 2012, there were totally 592 students sent to Japan for further study at the government's expenses, including 285 doctoral students and 177 undergraduates.

Japanese university provides the students who are major in Japanese and take part in cooperative cultivation project the other specialty besides Japanese. For example, Xi'an university has signed $2+2$ and 3+1 cooperative cultivation agreement with Josai international university. Josai international university has colleges of pharmacy, environtology, management information and media studies with subjects such as medicine, environmental sociology, comprehensive business and media information. From 2014 to 2016, there are totally 24 students from Xi' an university who take part in the cooperative cultivation project. Through the specialty learning of media information and environmental sociology in Josai international university, they master new professional knowledge and skills. Meanwhile, with the help of cooperative cultivation project, the cooperation and communication between teachers from Chinese and Japanese university has been developed, which practically improves the discipline construction, teachers' teaching level and students' comprehensive and application abilities.

\section{The Significance and Value of Establishing Cooperative Cultivation Project with Japanese University}

The significance and value of establishing cooperative cultivation project with Japanese university is to improve the diversified development of cultivation mode of talents, acquaint the students who are major in Japanese the social culture of Japan while they are learning Japanese, and they can also master other professional skills besides language. The Japanese and science and technological skills can be effectively combined with each other, which becomes an effective key to open the gate of employment market for students. Students can greatly dedicate themselves to local economic construction and cultural construction.

First of all, this project benefits to building up reasonable goal of talents cultivation, and conduct the talents cultivation of Japanese with science and technology.

Second, it helps students to improve their practical application ability and research ability.

Third, it helps to improve the reformation of education and teaching, and teachers' teaching ability.

Fourth, it makes the talents cultivation meet with the market demand and serve the local economy in a better way.

Fifth, in terms of the long-term effect of cooperative cultivation project, it benefits both sides to thoroughly communicate and deeply cooperate.

\section{The Idea and Method of Establishing Cooperative Cultivation Project with Japanese University}

\section{Idea}

First of all, a few Chinese universities will be selected as subject. The talents cultivation mode of Japanese specialty in Chinese universities and the current situation of cultivation project cooperated with Japanese university will be studied. Second, a few Japanese universities will be selected as representatives, and the specialty setup of Japanese universities will be investigated and observed. The contents, methods and steps of research should be clear. Third, teachers will be organized to study the contents, task and specific operation and study steps of the project, by which teachers can understand the learning situation of new specialty by students who took part in the cooperative cultivation projects, regulate the existing Japanese specialized courses setup, optimize the talents 
cultivation plan, improve the reformation of education and teaching, promotion and application.

\section{Method}

The field investigation combined with comparative analysis was adopted as research method. By field investigation, we can understand the specialty setup of Japanese universities and the talents cultivation mode of Japanese specialty in Chinese universities. Questionnaire and internet interview were used to study the specialty learning situation of those students who took part in the $2+2$ or $3+1$ project, by which we can understand the scope of talents urgently demanded by the job market, establish matched talents cultivation plan, deepen the cultivation mode cooperated with Japanese university and improve the investigation and practice of cultivation of talents with Japanese, science and technology.

\section{The Main Contents of Cultivation Project Cooperated with Japanese University}

\section{Optimizing of Talents Cultivation of Japanese Specialty}

According to teachers' study situation in Japanese university and students' specialty learning situation who took part in this project, and refer to the specialized course setup of Japanese university, the Japanese basic courses for junior grades (one, two grades) are reformed, by which the connection with the specialized course setup of Japanese university can be realized, and the cultivation mode of Japanese with science and technology can be established, and the talents cultivation plan will be more fit with the market demand.

\section{Improvement of Teachers' Specialized Skills}

Teachers can study the advanced teaching method of Japanese university through studying in Japanese university sponsored by government for half of a year to one year, by which they can update the teaching theory, improve the teaching skills combined with the actual situation of their own schools, and realize the connection with education and teaching method of Japanese university.

\section{Cultivation of Intercultural Communication Competence}

During the foundation curriculum stage, while we are trying to improve students' basic skills such as listening, speaking, reading, writing and translating, we should combine the knowledge on teaching materials with real-time information, and the actual development of the society, and train students' sensibility towards cultural difference, and their intercultural communication competence, by which students can quickly adapt to the Japanese social life.

\section{Promotion Benefits of Cultivation Project Cooperated with Japanese University}

It benefits to improving the reformation of education and teaching. Cooperative cultivation mode can timely respond whether the setting of cooperative cultivation mode of Japanese specialty talents is reasonable. Through optimizing the talents cultivation plan of Japanese specialty and each resource allocation of basic course, the teaching connection with Japanese university can be realized, and the discipline construction of Japanese specialty can be further improved.

It helps to cultivate the applied talents who are specialized in Japanese, science and technology, and to serve for the development of local economy. Under the cooperative cultivation mode of $2+2$, $3+1$, after students arrive in Japan, they choose a new specialty to learn in Japanese university, which aims to cultivate applied talents who are specialized in Japanese, science and technology.

It helps to improve students' ability of independent study and life, and establish self-confidence. Studying in Japan makes it possible for students to go abroad, and while their competence of Japanese, science and technology is improved, their ability of social resilience, study and live independently, adapting to new environment can be enhanced as well, which helps them to establish self-confidence.

It helps students to improve their competence of getting a job, adapting to the competition and development in society in future. And university can finally have characteristic specialty, and they can promote the application with other universities, which can lead the reformation of education and teaching in university. 


\section{Innovation of Cultivation Project Cooperated with Japanese University}

It reflects characteristics of the times of economic and cultural development. This research subject can enhance the foreign promotion of Chinese universities, make it possible to closely combine with economic and cultural development, create applied talents who are specialized in Japanese, science and technology and improve the economy development and cultural construction.

During the process of cooperative cultivation, students can utilize various advantages such as research perspective, method, teaching resources, scientific research environment and academic exchange platform from both universities and teachers, their vision of scientific research can be expanded, the ability and level of research will be improved.

While the reformation of teaching and teachers' professional skills are improved, more and more excellent double talents who are specialized in Japanese, science and technology are cultivated.

It benefits to improving the international academic communication. The study and experience abroad will win the opportunity of international communication for students. They are able to take part in all kinds of academic exchanges activity and are cultivated their comprehensive academic ability.

Research and practice cooperated with Japanese universities on cultivation of talents of Japanese, science and technology in The Thirteenth Five-Year Plan Of Science Of Education In Shaanxi Province -- taking Xi'an university as an example (Project Grand No.: SGH16H218).

\section{Reference}

[1] Bu Xianhua, You Shuhui, Research and cultivation strategy of the current Japanese language talents of enterprises in Jilin province, J. Changchun Uni. 21(10).

[2] Chen Yongming, Comparative research of Chinese and Japanese teacher and education system, 1994.

[3] Zhao Ruiqi, Current situation and strategy of talents cultivation of Japanese language in university, J Hebei North Uni (Social Sci). 2016.

[4] Statistics report of the number of people studying in Japan, 2013.

[5] Zhang Xuehuan, A view of the reformation of Japanese teaching in university in terms of employment, J Lanzhou Institute Edu, 2011.

[6] Zeng Zhiling, Revision principle of cultivation plan of applied talents specializing in Japanese, J Yangtze Uni (Social Sci), 2011, 34(6).

[7] Niu Lizhong, Niu Hui, Issues and strategy of talents cultivation of Japanese language in university under new situation, J Jilin TV Radio Uni, 2013.

[8] Li Aiwen, History, Actualities, and Outlook of China's Business Japanese Teaching, J Japanese Language Study Res, 2011.

[9] Zhang Peixia, Wu Yuchi, Current situation study of Japanese language teaching in the recent decade, J Japanese Language Study Res, 2013.

[10]Xiu Gang, Current situation and perspectives of Japanese language education in Chinese university-focusing on specialized Japanese teaching, J Japanese Language Study Res, 2008. 